\title{
O aktualności i atrakcyjności pewnego tematu
}

\author{
Pamięć, wybór, tożsamość. Szkice o mieście, red. K. Broński, \\ R. Kusek, J. Sanetra-Szeliga, Międzynarodowe Centrum Kultury, \\ Kraków 2016, 294 s.
}

Recenzowana monografia pod intrygującym i nadal modnym tytułem Pamięć, wybór, tożsamość. Szkice o mieście ukazała się w 2016 roku, stanowiąc kolejny projekt badawczy Międzynarodowego Centrum Kultury, którego misją jest interdyscyplinarna działalność naukowa i szeroko rozumiana aktywność popularyzatorska skupiona wokół dziedzictwa Europy Środkowej. Warto wspomnieć, że instytucja ta powstała tuż po upadku komunizmu z inicjatywy pierwszego niepodległego rządu polskiego, a zgłoszona została przez Tadeusza Mazowieckiego na Szczycie Paryskim Konferencji Bezpieczeństwa i Współpracy w Europie w 1990 roku. W obszarze zainteresowania MCK znajdują się takie zagadnienia, jak środkowoeuropejskie dziedzictwo kulturowe, sztuka i kultura, dialog międzykulturowy, polityka kulturalna i ekonomia kultury, wreszcie fenomen pamięci, tożsamości i miasta. I właśnie na tym ostatnim gruncie badawczym wyrósł omawiany zbiór szkiców o mieście w kontekście problematyki pamięciowej i tożsamościowej. Co więcej, powstał on z okazji jubileuszu dwudziestopięciolecia istnienia MCK i w hołdzie dla profesora Jacka Purchli - założyciela i dyrektora jednostki, pioniera w zakresie badań nad architekturą XIX i XX wieku, badacza dziedzictwa miasta i jego przestrzeni, a także twórcy nowoczesnej metodologii urbanologicznej.

Książka stanowi interesujące, różnorodne studium poświęcone metropolii jako wielopoziomowej, złożonej strukturze ukształtowanej pod wpływem różnych czynników, wciąż modyfikowanej przez światowe i lokalne kierunki rozwoju, idee, ideologie i procesy społeczne, polityczne, gospodarcze, kulturowe. Składające się na monografię teksty są zróżnicowane pod względem metodologicznym, materiałowym, a także w zakresie 
dyscyplin reprezentowanych przez autorów. Pomimo wyraźnie polimorficznego charakteru, różnorodności podejść badawczych i ujęć problemu, publikacja stanowi spójną całość ułożoną w logiczny ciąg opisowy; wszystkie teksty bowiem łączy zbliżone, jeśli nie wspólne, komplementarne definiowanie miasta jako przestrzeni heterogenicznej, wielopoziomowej, niejednoznacznej, w której niczym w laboratorium dochodzi do interakcji, interferencji i związków różnych światopoglądów, programów, tradycji. Metropolia jest zatem przedmiotem badań interdyscyplinarnych przy jednoczesnym zachowaniu zbieżnej perspektywy pojęciowej; opisywana przy pomocy rozmaitych metodologii, a zarazem ukazana w dość jednorodnych kategoriach definicyjnych.

Monografia została podzielona w nieoczywisty i subiektywny sposób, ułożona w porządku trójdzielnym - według podziału na trzy segmenty pomyślane jako swoiste sygnatury znajdujących się w nich tekstów: $W$ sercu kontynentu ${ }^{1}$, Re-kreacja, rewitalizacja, rozwój ${ }^{2}$, Kraków, mon amour $^{3}$. Taki rozkład monografii jest zrozumiały, jeśli wziąć pod uwagę, że uzasadnia go dedykacja wspomnianemu badaczowi, z którego dorobkiem naukowym mają korespondować opracowania pogrupowane właśnie w ten, a nie inny sposób. Natomiast w perspektywie szerszego odbioru zastosowany klucz podziału może wydawać się nieco enigmatyczny, nieczytelny. W żadnym razie nie jest to jakiś poważny zarzut, lecz tylko uwaga na temat dyskusyjności wyboru dokonanego przez redaktorów monografii. Niemniej jednak

${ }^{1}$ W sercu kontynentu - artykuły: Krzysztofa Brońskiego, Miasta galicyjskie we wspótczesnej historiografii. Przegląd badań i problemów; Żanny Komar, Worochta i „czarodziejska góra" Józefa Awina; Łukasza Galuska, Znamiona stołeczności - przypadek Pragi; Katarzyny Jagodzińskiej, Spór o muzeum. Rozważania o muzeach w przestrzeni Warszawy, Budapesztu i Pragi.

${ }^{2}$ Re-kreacja, rewitalizacja, rozwój - artykuły: Moniki Rydiger, Sztuka dla każdego? O sztuce publicznej w przestrzeni miasta; Natalii Żak, Moloch dziś niebieski, czyli wokót fenomenu polskich blokowisk; Ewy Wojtoń, Pamięć miasta poprzemysłowego na przykładzie Sosnowca; Joanny Sanetry-Szeligi, Kultura i rozwój miast. Wyzwania XXI wieku; Agaty Wąsowskiej-Pawlik, Miasto a kultura.

${ }^{3}$ Kraków, mon amour - artykuły: Michała Wiśniewskiego, Rozwój czy regres? Urbanistyka $i$ architektura $w$ sasiedztwie dzisiejszego kampusu Uniwersytetu Ekonomicznego w Krakowie w XIX i XX wieku; Heleny Postawki-Lech, Teatr władzy. Przyczynek do badań nad dekoracjami w przestrzeni miejskiej Krakowa w latach 1968-1989; Aleksandry Szczepan, Kraków w kryminale: na tropie wypartych pamięci; Roberta Kuska, ,,Il veleno di Auschwitz”. Literacki wizerunek Krakowa w prozie angielskojęzycznej XX $i$ XXI wieku. 
na poziomie merytorycznym ów trychotomiczny układ tekstów jest prawidłowy, w każdym bowiem bloku przedmiotowym znalazły się rozważania adekwatne do nadrzędnego oznaczenia, skoncentrowane wokół sygnalizowanego zakresu problemowego.

W pierwszej części zbioru zatytułowanej $W$ sercu kontynentu mieszczą się opracowania poświęcone miastom środkowoeuropejskim; mowa jest w nich m.in. o Warszawie, Budapeszcie, Pradze, Krakowie, Lwowie. Cechą wspólną tych szkiców jest wypracowany w nauce paradygmat odczytu przestrzeni miejskich, kontekst geokulturowy i imagologiczny oraz komparatystyczna strategia opisu, analiza zjawisk i procesów zachodzących na pograniczu wielu sfer - historii, kultury, sztuki, polityki, ekonomii i społeczeństwa. Refleksja wszystkich autorów pozostaje w dialogu z bogatym i ważnym dorobkiem naukowym profesora Purchli. Zgromadzone w tym bloku teksty dotyczą choćby stanu badań nad dziejami społeczno-gospodarczymi miast Galicji oraz kwestii wymagających uzupełnień w toku dalszych eksploracji tematu; stanowią próbę rekonstrukcji historii powstania modernistycznego zakładu leczniczego w Worochcie (obiektu niezbyt znanego, znajdującego się na terenach dzisiejszej Ukrainy) w aspekcie relacji sztuki narodowej i międzynarodowej; podnoszą problem wyobrażonej stołeczności środkowoeuropejskich metropolii na przykładzie Pragi z okresu austriackiego i austro-węgierskiego oraz kształtowania się narodowego charakteru ośrodków na obszarach bez podmiotowości państwowej; wreszcie także podejmują temat związków muzeum i miasta w odniesieniu do przestrzeni środkowoeuropejskich stolic - polskiej, węgierskiej i czeskiej, a także realnego oraz symbolicznego statusu muzeum.

Drugi segment monografii pod tytułem Re-kreacja, rewitalizacja, rozwój zawiera szkice eksponujące elementy kulturowe miasta i związane z nimi działania podejmowane przez lokalne władze i samych mieszkańców, jak również relacje kultury i gospodarki w odniesieniu do polskich metropolii. Rozważania badaczy odnoszą się do: przestrzeni miejskiej i sztuki publicznej, aktywności artystycznych kształtujących wizerunek metropolii i implikujących określone reakcje społeczne; kwestii powiązanych z rozwojem oraz społeczną i estetyczną rewitalizacją miasta na przykładzie blokowisk; problemu spuścizny industrialnej w kontekście poprzemysłowego krajobrazu miejskiego; zagadnienia współczesnych strategii rozwoju miasta i użyteczności kultury, polityki kulturalnej 
W rozwiązywaniu problemów miejskich; pytania o zmianę paradygmatu zarządzania kulturą miejską w perspektywie projektów samorządowych i obywatelskich.

W ostatnim bloku tematycznym znamiennie oznaczonym mianem Kraków, mon amour, poświęconym krakowskiemu ośrodkowi, najbliższemu prywatnie i zawodowo profesorowi Purchli, znalazły się teksty skoncentrowane wokół definicji miasta jako swoistego laboratorium przemian, napięć pomiędzy historią a współczesnością, nowoczesnością; jako przestrzeni ujawniającej tradycję i zmianę, odzwierciedlającej procesy transformacyjne, jakie objęły cały obszar środkowoeuropejski. Autorzy dokonują analizy wielu płaszczyzn i aspektów funkcjonowania metropolii, rozpoznają określone mechanizmy rozwojowe na przykładzie kampusu uniwersyteckiego; trafnie wskazują artystyczne projekcje władzy i dominacji w przestrzeni miejskiej w odwołaniu do dekoracji okolicznościowych powstałych w okresie PRL; w końcu umiejętnie prezentują także literacki wizerunek miasta w oparciu o rodzime powieści kryminalne, których akcja toczy się w Krakowie czy literaturę angielskojęzyczną, wielokrotnie w swej fabule nawiązującą do tego właśnie miasta, w ostatnich latach trwale łączącą z nim temat Holocaustu.

Monografia jako całość stanowi interesujące studium o mieście w kontekście pamięci i tożsamości; wielokierunkowa i wielowątkowa narracja wprowadza czytelnika w problematykę związaną z przestrzenią miejską zarówno w wymiarze uniwersalnym, jak i regionalnym czy lokalnym. Przy dużej różnorodności tematycznej i materiałowej zbioru szkiców ich autorom udało się zachować wspólne komponenty definicyjne, kategorie określające metropolię jako wypadkową fenomenów oraz procesów historycznych, kulturowych, politycznych, społecznych i ekonomicznych. Podobnie rzecz wygląda z nakreślonym zasięgiem badawczym, refleksja wszystkich autorów konsekwentnie koncentruje się na obszarze Europy Środkowej, ukazując jej skomplikowany i niejednoznaczny obraz, eksponując uwikłanie dziejowe, bagaż doświadczeń odzwierciedlający się w miejskiej tkance, wreszcie też wskazując możliwe kierunki i rozwiązania problemów trawiących ten teren w przeszłości i obecnie. Dodatkową, niepodważalną wartością tego zbioru jest jego dialog z dorobkiem naukowym profesora Jacka Purchli, który od lat prowadzi badania nad rozwojem miast, historią społeczną, historią sztuki XIX i XX stulecia, dziedzictwem kulturowym. 
Warto dodać, że interdyscyplinarny charakter badań założyciela i dyrektora Międzynarodowego Centrum Kultury znalazł swój wyraz w tekstach, składających się na poświęconą mu monografię. Szerokie i zróżnicowane ujęcie tematu, będące wynikiem ścisłej współpracy naukowców stosujących metody badawcze typowe dla swych dyscyplin, nadało projektowi walor nowości, swoistego usytuowania ponad granicami tradycyjnego opisu, wyjścia poza ramy jednej teorii i praktyki metodologicznej, a tym samym posłużyło ożywieniu i ukierunkowaniu dyskusji nad fenomenem miasta jako konstruktem niejednorodnym w wymiarze realnym i symbolicznym. Wszystkie szkice można uznać za spójną narrację o metropolii widzianej niczym w soczewce skupiającej zaszłości, perturbacje i trudności oraz jako laboratorium, w którym dochodzi do swoistego zderzenia starego z nowym, powstają wzory nieoczywistych substancji ujawniających nowo odkryte pierwiastki budujące tkankę miejską. Monografię spaja szczególnego rodzaju optyka badawcza - traktowanie miasta w kategoriach swoistego tekstu będącego odzwierciedleniem dziedzictwa i nowoczesności, ujmowanie go jako ideowej konstrukcji, kulturowej funkcji, społecznej formy i historyczno-politycznego procesu. Takie stanowisko z kolei sygnalizuje konieczność rozwinięcia czy udoskonalenia instrumentarium metodologicznego, jakie mogłoby służyć opisowi fenomenu miasta w najszerszym jego znaczeniu, co właśnie uwidocznia recenzowany zbiór szkiców.

Przy wielkim uznaniu dla naukowych prezentacji zawartych w recenzowanym zbiorze, przy jednoznacznie pozytywnej ocenie całego przedsięwzięcia, należy odnotować także pewne niedostatki, które owa monografia ujawnia. Jak zostało już powiedziane, najpoważniejsze zastrzeżenia budzi sam podział na zakresowe segmenty, jego pewna nieczytelność dla szerszego grona odbiorców. Ponadto pewnym brakiem zdaje się nieobecność w monografii ogólnego résumé w języku obcym (po angielsku lub w innym języku kongresowym), a także streszczeń czy choćby abstraktów towarzyszących wszystkim szkicom, co wprawdzie nie jest obligatoryjne w tego typu publikacjach, ale znacząco podniosłoby poziom popularyzacji. Choć forma szkicu naukowego zwalnia jego autora z restrykcji obejmujących tradycyjny artykuł naukowy, nie wymaga opatrzenia tekstu obcojęzycznym opisem, jednak akurat w tym konkretnym przypadku - ze względu na wysoki poziom rozważań i fakt, że publikacja powstała w Międzynarodowym Centrum Kultury - niedobór takich streszczeń zupełnie niepotrzebnie 
osłabia odbiór monografii i ogranicza jej recepcję niemalże wyłącznie do rodzimego obiegu. Pobocznym problemem, aczkolwiek istotnym w świetle funkcjonowania zbioru na rozległym rynku czytelniczym, jest nieobecność jakichkolwiek informacji (not) o samych autorach i reprezentowanych przez nich dyscyplinach naukowych, co oczywiście w tym przypadku nie jest wymogiem, jednak nie sprzyja rozpoznaniu choćby w środowisku niewyspecjalizowanym. Niewątpliwie wymienione tu pewne niedociągnięcia nie obniżają wartości tego interesującego zbioru szkiców, a ich wskazanie ma być jedynie pomocne w kontekście przyszłych projektów realizowanych przez MCK, na co liczy pisząca te słowa, zresztą jak i - bez wątpienia - wielu innych badaczy.

Podsumowując, należy stwierdzić, że rekomendowana czytelnikowi monografia Pamięć, wybór, tożsamość. Szkice o mieście wydana z okazji okrągłego jubileuszu dwudziestopięciolecia istnienia Międzynarodowego Centrum Kultury i dedykowana jego założycielowi i dyrektorowi, stanowi ważną propozycję naukową, która wpisuje się w nurt nowoczesnych badań metropolitalnych, łączących wiele dziedzin i dyscyplin, odwołujących się do sfery faktów i wyobrażeń, definiujących i redefiniujących szereg idei, konstrukcji i tradycji składających się na obszerne pojęcie miasta. Należy dodać, że omawiana publikacja dotyczy obszaru środkowoeuropejskiego i w tym sensie nie tylko porusza przedmiotowy problem w określonym, regionalnym kontekście, ale również czy przede wszystkim służy dowartościowaniu, włączeniu tego terenu w nurt nowoczesnych badań w skali uniwersalnej. Co więcej, ów zbiór szkiców jest swoistym zwieńczeniem naukowej, kulturalnej i społecznej aktywności badawczej MCK, wzbogacającym istniejący korpus wydawniczy. W tym świetle niniejsza recenzja ma na celu zarówno wyrażenie opinii - skądinąd bardzo pochlebnej - jak i popularyzację osiągnięć Centrum. Nade wszystko zaś ma ona zachęcić czytelnika do lektury tej istotnej propozycji naukowej, która, mimo że wpisuje się w wieloletni już nurt eksploatacji problemu, to jednak w wielu miejscach kładzie nowe akcenty, wskazuje ciekawe rozwiązania w przedmiotowym zakresie. Konkludując, należy podkreślić ważkość podjętego tematu, który okazuje się wciąż aktualny i atrakcyjny, otwierający kolejne możliwości i perspektywy badawcze, czemu omawiana monografia doskonale daje wyraz. 